\title{
Topically applied antibody fragments penetrate into the back of the rabbit eye
}

Abstract

Aims Antibody fragments have been shown to penetrate into the anterior chamber when applied to the cornea. The aim of this study was to investigate whether such fragments could penetrate into the vitreous cavity after topical administration to the ocular surface of rabbits.

Methods An engineered single-chain variable-domain antibody fragment with specificity for an irrelevant rat determinant was applied as a $50 \mu$ l eye drop to the eyes of live rabbits at 20-min intervals over $12 \mathrm{~h}$. Eye drops contained $0.8-1.1 \mathrm{mg} / \mathrm{ml}$ protein in a buffered salt solution supplemented with penetration and viscosity enhancers. Samples were collected by paracentesis from the vitreous cavity immediately postmortem.

${ }^{1}$ Department of Ophthalmology

Flinders University of South Australia Adelaide, Australia

${ }^{2}$ CSL Research and Development CSL Ltd Parkville Victoria, Australia

Correspondence: KA Williams Department of Ophthalmology Flinders Medical Centre Bedford Park SA 5042 Australia

Tel: + 61882045047

Fax: 61882770899

E-mail: keryn.williams@

flinders.edu.au

Received: 19 December 2003

Accepted: 8 June 2004

Published online:

3 September 2004
Antibody fragments in these samples were quantified by measuring the binding activity to specific antigen, using flow cytometry.

Results Topically applied antibody fragments were detectable in the vitreous of rabbit eyes after $4-12 \mathrm{~h}$ but had cleared at $12 \mathrm{~h}$ following the final eye drop. Concentrations of the antibody fragment in the vitreous samples were estimated to be $50-150 \mathrm{ng} / \mathrm{ml}$ at $12 \mathrm{~h}$. Penetration of the parental whole antibody into the vitreous was not observed.

Conclusion Antibody fragments penetrate into the vitreous chamber of the rabbit eye after topical administration to the ocular surface. Such fragments may have therapeutic potential for diseases affecting the posterior segment.

Eye (2005) 19, 910-913. doi:10.1038/sj.eye.6701669; published online 3 September 2004

Keywords: engineered antibody fragments; therapeutics; vitreous
KA Williams', HM Brereton', A Farrall', SD Standfield ${ }^{1}$, SD Taylor ${ }^{2}$, LA Kirk² and DJ Coster ${ }^{1}$
Introduction

Recombinant antibodies ${ }^{1}$ and antibody fragments ${ }^{2}$ are useful therapeutic drugs for a wide spectrum of conditions, but are seldom used in clinical ophthalmology. The reasons are multifactorial but include the morbidity that can be associated with systemic administration. Whole antibody molecules are relatively large proteins $(\geqslant 150 \mathrm{kDa})$ that do not pass across the ocular surface when delivered topically. ${ }^{3}$ We have recently shown that some monovalent and divalent antibody fragments can penetrate across the ocular surface into the anterior chamber of the eyes of pig, cat, rabbit, and human when administered in eye drop form. ${ }^{4}$ We thus decided to investigate the penetration of topically applied antibody fragments into the posterior segment of the eye.

\section{Materials and methods}

Eye drops contained a single-chain variabledomain fragment ( $\mathrm{scFv}$ ) with specificity for the rat CD4 molecule that had been generated from the murine hybridoma OX38 (European Collection of Animal Cell Cultures, Porton Down, Wiltshire, UK) as previously described. ${ }^{4}$ The scFv was expressed in Escherichia coli and purified on an immobilised metal affinity column followed by passage over Q-Sepharose resin at CSL Ltd (Parkville, VIC, Australia).

Three separate batches of $\mathrm{scFv}$ were fermented and purified to $91-94 \% \mathrm{scFv}$ protein. The fragment was formatted with a 20-amino-acid linker joining the $\mathrm{VH}$ and VL immunoglobulin domains: size exclusion chromatography indicated presence of both monomers and natural dimers. For administration to rabbits in eye drop form, the $\mathrm{scFv}$ was dissolved in $150 \mathrm{mM} \mathrm{NaCl}, 10 \mathrm{mM}$ HEPES buffer $\mathrm{pH} 8.0$ supplemented with $0.5 \%$ sodium caprate 
(Sigma Chemical Company, St Louis, MO, USA) to enhance penetration of the protein ${ }^{5,6}$ and $1.5 \%$ hydroxypropyl methylcellulose (Dow Chemical Pacific Ltd, Marleston, South Australia, Australia) to increase viscosity of the eye drop. The final protein concentration of the formulated eye drops containing $\mathrm{scFv}$ was 0.8 $1.1 \mathrm{mg} / \mathrm{ml}$. The endotoxin level of these preparations was less than 0.5 endotoxin units $/ \mathrm{ml}$ as measured by the Limulus Amebocyte lysate test (Bio Whittaker, Walkerville, MD, USA). OX38 parental antibody (IgG) was used as the control eye drop at a concentration detectable at a dilution of 1 in 30000 by flow cytometry.

Adult Dutch Belted rabbits were used in the first experiment and New Zealand white rabbits were used in the second and third experiments. Each rabbit was individually caged but was otherwise unrestrained, and was allowed unlimited access to rabbit chow, water and environmental enrichment toys throughout the experiment. All experimentation was performed with approval from the institutional Animal Welfare Committee and in accordance with current legislation.

In the first experiment, one eye of each of four rabbits was treated with $\mathrm{scFv}$ eye drops by topical application of one $50 \mu \mathrm{l}$ drop to the cornea every $20 \mathrm{~min}$ for up to $12 \mathrm{~h}$. One rabbit was withdrawn from treatment at each of 4,6, 8 , and $12 \mathrm{~h}$. An additional rabbit was treated every $20 \mathrm{~min}$ for $12 \mathrm{~h}$ but was not killed until $12 \mathrm{~h}$ after cessation of treatment. One rabbit was treated for $12 \mathrm{~h}$ with IgG instead of scFv. One rabbit was killed at zero time without having undergone any treatment. Peripheral blood was collected from the ear vein immediately prior to euthanasia, allowed to clot, and the serum separated. Rabbits were euthanised by intravenous administration of $5 \mathrm{ml}$ of $325 \mathrm{mg} / \mathrm{ml}$ veterinary sodium pentobarbitone (Arnolds of Reading Pty Ltd, Boronia, Victoria, Australia) into the marginal ear vein. All eyes were then vigorously irrigated with $20 \mathrm{ml}$ sterile normal saline and gently dried with surgical gauze before ocular samples were collected. Samples of vitreous were collected by paracentesis using a $1 \mathrm{ml}$ tuberculin syringe fitted with an 18 gauge needle. Sample size was 100-300 $\mu \mathrm{l}$. Once collected, all samples were supplemented with $2 \mu \mathrm{l} 4 \mathrm{M}$ sodium azide and were chilled to $4^{\circ} \mathrm{C}$. To control for possible contamination of ocular fluid samples during the collection process, one untreated eye was treated topically with the $\mathrm{scFv}$ preparation immediately after euthanasia of the rabbit, the eye was irrigated with saline and the sample collected $30 \mathrm{~s}$ later, at a time at which penetration of the $\mathrm{scFv}$ into the eye would not have been anticipated.

In the second and third experiments, one eye of each of five rabbits was treated with $\mathrm{scFv}$ eye drops by topical application of one $50 \mu \mathrm{l}$ drop to the cornea every $20 \mathrm{~min}$ for up to $12 \mathrm{~h}$. One rabbit was withdrawn from treatment at each of $4,6,8,10$, and $12 \mathrm{~h}$. Vitreous samples were collected and treated as described above. Ocular fluids were also collected from untreated eyes and from eyes treated topically with one drop of the $\mathrm{scFv}$ preparation immediately after euthanasia of the rabbit.

Binding activity of the parental antibody or the $\mathrm{scFv}$ was measured by flow cytometry on normal rat thymocytes that had been purified over a Lymphoprep (Nycomed Pharma, Oslo, Norway) cushion. ${ }^{4}$ Assays were performed in duplicate or triplicate. Geometric mean fluorescence intensity (MFI) was used as a relative quantitative measure for $\mathrm{scFv}$ or intact IgG concentration, by reference to a dilution series of purified protein of known concentration. Maximum MFIs of the three batches of scFv used in experiments 1-3 were 209, 146 , and 241 , respectively.

\section{Results}

Eye drops were applied without the need for restraint or topical anaesthetic and were well tolerated, although some rabbits did groom periocular fur and then lick their paws during the experiment. Mild conjunctival hyperaemia was noted in some rabbits as the experiment progressed.

In the first experiment, $\mathrm{scFv}$ was detectable by flow cytometry in the vitreous of treated rabbit eyes at $4 \mathrm{~h}$ after initiation of treatment, and thereafter to $12 \mathrm{~h}$, although relatively poor penetration was observed in the rabbit treated for $8 \mathrm{~h}$ (Table 1). Accumulation of the fragment did not appear to occur. The amount of $\mathrm{scFv}$ applied to the ocular surface in a single eye drop was $40 \mu \mathrm{g}$ of protein, and the amount of $\mathrm{scFv}$ in the vitreous sample at 4-6 and $12 \mathrm{~h}$ was estimated to be 700 and $80 \mathrm{ng} / \mathrm{ml}$, respectively. At $24 \mathrm{~h}$ after initiation of treatment and $12 \mathrm{~h}$ after cessation of treatment, no detectable $\mathrm{scFv}$-binding activity remained in the vitreous. No binding activity was detected in vitreous collected from any contralateral, untreated eye, and serum samples were uniformly negative. No antigen-binding activity was found in the vitreous fluid of the eye treated for $12 \mathrm{~h}$ with IgG.

In the second and third experiments, unequivocal evidence of penetration into the vitreous as assessed by mean fluorescence intensity was not observed until $12 \mathrm{~h}$ after initiation of topical treatment (Table 1), although flow cytometry overlays indicated some penetration after $4 \mathrm{~h}$ of treatment (Figure 1). The amounts of $\mathrm{scFv}$ in the vitreous samples at $12 \mathrm{~h}$ in experiments 2 and 3 were estimated to be 50 and $150 \mathrm{ng} / \mathrm{ml}$, respectively. Some evidence of systemic absorption of $\mathrm{scFv}$ was noted in the third experiment, as evidenced by positivity in serum samples. 
Table 1 Penetration of antibody or antibody fragments into the vitreous of the rabbit eye after topical application to the ocular surface, as measured by flow cytometry against rat thymocyte target cells

\begin{tabular}{|c|c|c|c|c|c|c|c|c|c|c|}
\hline \multirow[t]{2}{*}{$\operatorname{Exp}^{\mathrm{a}}$} & \multirow[t]{2}{*}{ Sample } & \multicolumn{9}{|c|}{ Mean fluorescence intensity of anti-CD4 scFv } \\
\hline & & Drop & $0 h r$ & $30 s^{\mathrm{b}}$ & $4 h r^{c}$ & $6 h r$ & $8 h r$ & $10 \mathrm{hr}$ & $12 \mathrm{hr}$ & $24 h r^{\mathrm{d}}$ \\
\hline \multirow[t]{3}{*}{1} & Vitreous & $\mathrm{scFv}$ & 5 & 4 & 319 & 317 & 22 & $\mathrm{NT}^{\mathrm{e}}$ & 76 & $7^{*}$ \\
\hline & Serum & $\mathrm{scFv}$ & 4 & 10 & 14 & 17 & 10 & NT & 17 & 10 \\
\hline & Vitreous & $\operatorname{IgG}$ & NT & NT & NT & NT & NT & NT & 5 & NT \\
\hline \multirow[t]{2}{*}{2} & Vitreous & $\mathrm{scFv}$ & 2 & $3,4,7$ & 6 & 6 & 9 & 7 & 20 & NT \\
\hline & Serum & $\mathrm{scFv}$ & NT & NT & 7 & 7 & 12 & 14 & 8 & NT \\
\hline \multirow[t]{2}{*}{3} & Vitreous & $\mathrm{scFv}$ & 5,3 & $5,13,21$ & 5 & 12 & 4 & 5 & 79 & NT \\
\hline & Serum & $\mathrm{scFv}$ & NT & NT & 96 & 57 & 18 & 21 & 31 & NT \\
\hline
\end{tabular}

${ }^{\mathrm{a}} \mathrm{Exp}=$ experiment number.

$\mathrm{b}_{\mathrm{s}}=$ seconds.

$\mathrm{c} h \mathrm{r}=$ hours.

${ }^{\mathrm{d}}$ Rabbit treated thrice hourly for $12 \mathrm{~h}$ and then rested for a further $12 \mathrm{~h}$.

${ }^{\mathrm{e}} \mathrm{NT}=$ not tested.

Each datum point represents a separate bleed or eye.

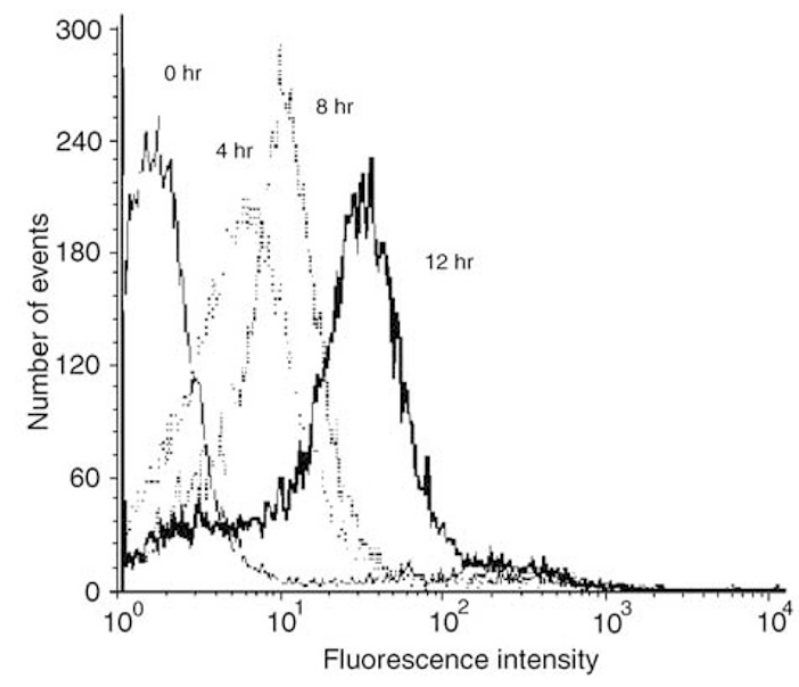

Figure 1 Flow cytometry histograms showing CD4-binding activity of rabbit vitreous samples from experiment \#2 with normal rat thymocytes; $0 \mathrm{hr}$ represents a sample from an untreated eye, $4 \mathrm{hr}, 8 \mathrm{hr}$, and $12 \mathrm{hr}$ represent samples from eyes treated topically with anti-CD4 scFv for 4,8 , and $12 \mathrm{~h}$ respectively.

\section{Discussion}

An anti-rat $\mathrm{CD} 4 \mathrm{scFv}$ was found to be present in rabbit vitreous samples after 4-12 h of topical application. Antibodies and derived antibody fragments reactive against the rat CD4 determinant are not cross-reactive with rabbit cells or ocular tissue, and thus do not bind to the rabbit ocular surface or to any structures within the rabbit eye. Should these proteins be capable of ocular penetration, they will thus not be retarded by specific binding to ocular structures. Delivery into the posterior segment via systemic absorption (either from nasolacrimal drainage or ingestion as a result of grooming) and subsequent diffusion through the paucivascular retinal circulation of the rabbit may have contributed to the outcomes observed in the third experiment, but not to the outcomes of the first and second experiments, given that serum levels of $\mathrm{scFv}$ in the latter were low. As anticipated from the work of others $^{3}$ and from our own previous findings, ${ }^{4}$ whole immunoglobulin was unable to penetrate through the ocular surface into the eye over the time frame of the experiments described.

Penetration of $\mathrm{scFv}$ into the rabbit vitreous was somewhat variable, depending on the individual animal and possibly upon the strain. Within the experiment using Dutch Belted rabbits, which are pigmented, antibody fragments were readily detectable in vitreous fluid at $4 \mathrm{~h}$, compared with somewhat later times in the larger, albino New Zealand white rabbits.

Topical or local administration is the preferred treatment option for the majority of widely prescribed ophthalmic medications. Our data suggest that, somewhat unexpectedly, a protein of approximately $28 \mathrm{kDa}$, applied topically to the tear film, can penetrate through the ocular surface and pass into the posterior segment of the eye with retention of antigen-binding capacity. In our experiments, the estimated concentration of $\mathrm{scFv}$ in the rabbit vitreous after $12 \mathrm{~h}$ of topical therapy ranged from 50 to $150 \mathrm{ng} / \mathrm{ml}$, concentrations potentially of therapeutic benefit. Our findings have interesting implications: for any condition affecting the posterior segment in which an antibody might act as a useful antigen trap, an scFv or similar antibody fragment might be able to be delivered by topical application in a convenient eye drop. 


\section{Acknowledgements}

We acknowledge the expertise of A Yusim, G Turner and A Moisidis (all from CSL Ltd) in producing and purifying antibody fragments. Ms K Marshall provided expert assistance with experimental animals. This work was supported by the NH\&MRC of Australia, the Ophthalmic Research Institute of Australia, and the Flinders Medical Centre Foundation. CSL Ltd has a proprietary interest in this work.

\section{References}

1 Breedveld FC. Therapeutic monoclonal antibodies. Lancet 2000; 355: 735-740.
2 Hudson PJ, Souriau C. Engineered antibodies. Nat Med 2003; 9: 129-134.

3 Allansmith M, de Ramus A, Maurice D. The dynamics of IgG in the cornea. Invest Ophthalmol Vis Sci 1979; 18: 947-955.

4 Thiel MA, Coster DJ, Standfield SD, Brereton HM, Mavrangelos C, Zola $\mathrm{H}$ et al. Penetration of engineered antibody fragments into the eye. Clin Exp Immunol 2002; 128: 67-74.

5 Morimoto K, Nakamura T, Morisaka K. Effect of mediumchain fatty acid salts on penetration of a hydrophilic compound and a macromolecular compound across rabbit corneas. Arch Int Pharmacodyn Ther 1989; 302: 18-26.

6 Sasaki H, Igarashi Y, Nagano T, Nishida K, Nakamura J. Different effects of absorption promoters on corneal and conjunctival penetration of ophthalmic beta-blockers. Pharm Res 1995; 12: 1146-1150. 